\title{
Retraction of A Bibliometric Analysis of the Papers on Urban Education
}

\author{
Ye Liang *, Lindong Wang
}

Issue Date: 17 December 2018

Original Article: A Bibliometric Analysis of the Papers on Urban Education EURASIA J. Math., Sci Tech. Ed (2018), 14(7), 2857-2866.

https://doi.org/10.29333/ejmste/90019

This document states that the Article is retracted. All authors agree to the retraction of the Article.

\section{http://www.ejmste.com}

